\title{
Increased Cell Membrane Permeability in the Pathogenesis of Hereditary Spherocytosis *
}

\author{
Harry S. Jacob and James H. Jandl with the technical assistance of \\ Susan C. Bell and Nancye M. Files \\ (From the Thorndike Memorial Laboratory and Second and Fourth [Harvard| Medical Sir' \\ ices, Boston City Hospital, and the Department of Medicine. Hariard Medical \\ School, Boston, Mass.)
}

The hemolytic process in hereditary spherocytosis (HS) is presumed to involve an intrinsic defect in the structure or metabolism of the red cell (1-3). The nature of the basic cellular defect remains enigmatic, although its manifestations are well characterized. Distinctive features of the HS red cell are its more spheroidal shape, small surface area, and high hemoglobin concentration and its exceptional proclivity toward splenic sequestration. However, the most singular feature of these cells is their abnormally rapid spheroidal change and increase in osmotic fragility on sterile incubation in vitro (4-6). This characteristic response of $\mathrm{HS}$ red cells has provided the most reliable method for diagnosis of the disorder (7).

Efforts to identify a presumed biochemical lesion in HS red cells have had little success. A reported diminution in turnover of organic phosphate esters (8) has not been confirmed $(9,10)$, nor have abnormalities been found in the concentrations or kinetics of glycolytic intermediates or in glucose consumption of HS red cells $(6,11$, 12). More recently, evidence has been presented $(13,14)$, but later denied $(15,16)$, that an abnormality exists in the phospholipids of the red cell membrane in this disease. With incubation, increased loss in lipids from spherocytic membranes has also been reported $(17,18)$.

The general presumption in studies of HS red cells has been that a deficit existed in their energy metabolism. This presumption is difficult to reconcile with the findings by Harris and Prankerd (19) and Bertles (20) that the sodium efflux and influx, respectively, across HS cell membranes are

* Submitted for publication December 9, 1963 ; accepted April 23, 1964.

Supported by U. S. Public Health Service research grant HE-07652-01, National Heart Institute, Bethesda, Md. actually increased, since increased sodium transport should be reflected by heightened, rather than diminished, energy metabolism (21-23).

In view of the inconsistencies noted above, the present studies were undertaken to attempt to characterize anew the over-all metabolic behavior of HS red cells and to relate changes in their metabolism on erythrostasis in vitro to changes in their viability in vivo. A preliminary report of these findings has been published (24).

\section{Methods}

Eight patients, all of whom had been splenectomized in the past, served as donors of HS red cells. The patients, from five families, demonstrated normal routine blood counts (25), including reticulocyte percentages, at the time of the studies. The following characteristics, considered typical of the disease, were present in every donor: a) a congenital hemolytic anemia affecting at least two family members; $b$ ) complete clinical remission following splenectomy; $c$ ) spherocytes demonstrable on peripheral smear with associated increased osmotic fragilities of fresh and of incubated blood; and $d$ ) abnormal degrees of autohemolysis following prolonged incubation, partially corrected by adding glucose.

Fresh blood, drawn into heparin, was centrifuged at $3,000 \mathrm{rpm}$, the buffy coat was removed, and the cells were resuspended in an incubation medium rendered sterile by Seitz filtration. After recentrifugation and a second removal of any remaining buffy coat, resuspension in the incubation medium to an approximate $35 \%$ cell suspension was effected. Leukocytes in these washed suspensions numbered less than 200 per $\mathrm{mm}^{3}$. The incubation medium, unless otherwise stated, was a buffered $5 \%$ dialyzed human serum albumin ${ }^{1}$ solution containing the fol-

\footnotetext{
1 Normal human serum albumin was obtained from Massachusetts Public Health Biologic Laboratories as a $25 \%$ solution. After dialysis against appropriate buffer the solution was diluted to a final concentration of $5 \%$ in buffer. Previous studies $(26,27)$, especially evidence recently presented (28), indicate that plasma when incubated undergoes alterations in its lipid moieties that
} 
lowing constituents: $\mathrm{K}=6.5 \mathrm{mEq}$ per $\mathrm{L}, \mathrm{Na}=165 \mathrm{mEq}$ per $\mathrm{L}, \mathrm{PO}_{4}=40$ mmoles per $\mathrm{L}, \mathrm{HCO}_{3}=25 \mathrm{mEq}$ per $\mathrm{L}$, and $\mathrm{Cl}=$ balance of anions. The medium was isosmolal with normal plasma by freezing point depression determination. When pertinent, additives to the medium were present in the following concentrations : glucose, $0.022 \mathrm{M}$; ouabain, ${ }^{2} 3.5 \times 10^{-5} \mathrm{M}$; sucrose, $0.08 \mathrm{M}$.

The cell suspension was equilibrated to a $\mathrm{pH}$ of approximately 7.4 with a $95 \%$ oxygen and $5 \%$ carbon dioxide mixture before incubation. After removal of a sample of cells for initial metabolic determinations, the remaining cell suspension was further divided and incubated at $37^{\circ} \mathrm{C}$ in a number of stoppered vessels without shaking unless otherwise noted. At various intervals thereafter one sample was labeled for 30 minutes at $25^{\circ}$ $\mathrm{C}$ with $150 \mu \mathrm{c}$ of $\mathrm{Cr}^{51}$-labeled sodium chromate. ${ }^{3}$ After free chromate was removed with a single centrifugation, the cells were suspended in normal saline and were then injected into serologically compatible normal subjects. Red cell survival and the sites of sequestration were studied as described previously (29). At the time of injection and at intervals thereafter additional samples of cells were removed from the separate incubation flasks for metabolic studies. In all experiments the metabolism and survival of HS red cells were compared to those of red cells from normal subjects incubated at the same time under identical conditions.

Duplicate hematocrits determined in Wintrobe tubes were in agreement to within $\pm 1 \%$. Ancillary studies with $\mathrm{I}^{131}$-labeled albumin demonstrated no significant variation in plasma trapping during these experiments, as noted previously by others (30). Therefore, no correction for plasma trapping was made. The $\mathrm{pH}$ of red cell suspensions was measured in a Beckman model G $\mathrm{pH}$ meter at various intervals during incubation. Red cell lactate production by the lactate dehydrogenase 4 method (31) and glucose consumption by the SomogyiNelson method (32) were determined in duplicate assays from duplicate incubation flasks agitated for 4 hours at $37^{\circ} \mathrm{C}$. Cellular $\mathrm{Na}$ gain and $\mathrm{K}$ loss during the incubation were calculated as described previously (33) from measurements of extracellular and whole-blood cation levels obtained by internally standardized flame photometry. The cellular cation concentrations were

produce changes in the shape and fragility of red cells. Albumin media, containing approximately $10^{-4} \mathrm{M}$ protein-bound fatty acid, were used in these studies in order to circumvent variables that might be associated with such plasma alterations.

2 Ouabain U.S.P., obtained from Eli Lilly Company, Indianapolis, Ind., was diluted 10 -fold in incubation medium before use.

3 Available as Rachromate from Abbott Laboratories, North Chicago, Ill.

4 Assay reagents produced by C. F. Boehringer and obtained in kit form from California Corp. for Biochemical Research, Los Angeles, Calif. related to the original volume of cells. In control studies these values agreed closely with those measured in hemolysates from cell suspensions washed with isotonic $\mathrm{MgCl}_{2}(0.1 \mathrm{M})$. The method of Grunert and Phillips (34), as modified by Beutler (35), was used to assay glutathione (GSH) content in red cells. Red cell osmotic fragility was measured by the method of Emerson and his associates (4); in incubation mixtures containing sucrose, however, an initial 1:100 dilution of blood in the hypotonic salt solutions was used to render negligible the osmotic activity contributed by this substance.

Measurements of radioactive $\mathrm{CO}_{2}$ derived from cell suspensions incubated with $\mathrm{C}^{14}$-glucose ${ }^{5}$ were made by the use of incubation bottles containing removable plastic wells of Hyamine, as described by Goodner and Freinkel (36). The incubation was begun with the addition of tracer amounts of the labeled glucose to cells suspended in the usual $5 \%$ buffered albumin medium containing 150 $\mathrm{mg}$ per $100 \mathrm{ml}$ carrier glucose. Approximately $0.1 \mu \mathrm{c}$ of $\mathrm{C}^{14}$-glucose was added to each $1 \mathrm{ml}$ of $35 \%$ cell suspension. After agitation in a $37^{\circ} \mathrm{C}$ water bath for 4 hours, $0.2 \mathrm{ml}$ of $1 \mathrm{~N} \mathrm{H}_{2} \mathrm{SO}_{4}$ was added to the red cell suspension through the rubber diaphragmatic top of the incubation bottle. After its evolution and subsequent trapping in the plastic well containing Hyamine, $\mathrm{C}^{14} \mathrm{O}_{2}$ was counted in a methanol-toluene solution of 2,5-diphenyloxazole- $p$ bis 2-(5-phenyloxazolyl)-benzene ${ }^{6}$ in a Packard Tri-Carb liquid scintillation counter with toluene- $\mathrm{C}^{14}$ as an internal standard. From a knowledge of the counts of $\mathrm{C}^{14}$-glucose added, the total glucose consumption, and the $\mathrm{C}^{14} \mathrm{O}_{2}$ counts produced, the percentage of utilized glucose metabolized to $\mathrm{CO}_{2}$ was calculated.

Influx and efflux of sodium in red cells was measured by using tracer ${ }^{7} \mathrm{Na}^{24}$. Sodium influx was measured in $30 \%$ cell suspensions incubated in glucose-containing media. Samples of cells, removed at various times, were washed 3 times in isotonic $\mathrm{MgCl}_{2}$ over a period of 10 minutes. Radioactivity of hemolysates derived therefrom was measured in a well-type scintillation counter. The radioactivity of the suspending medium was also measured at each interval. Total sodium concentrations of the hemolysate and suspending medium were obtained by flame photometry. Calculation of $\mathrm{Na}$ influx from these data was made by utilizing the formulas derived by Solomon (37), as modified by Bertles (20). Sodium efflux was measured after preincubation of red cells with $\mathrm{Na}^{24}$ for 2 hours in glucose-containing media. After three washes and resuspension in a tracer-free medium, a sample of blood suspension was removed for counting, and the remaining blood was reincubated. The medium was sampled and counted at various intervals thereafter. Intracellular activity at each interval was calculated by

\footnotetext{
5 Obtained from New England Nuclear Corp., Boston, Mass.

${ }^{6}$ Available as Liquifluor, a $25 \times$ concentrated solution, from Pilot Chemicals, Inc., Watertown, Mass.

7 Available from Iso-Serve, Inc., Cambridge, Mass.
} 

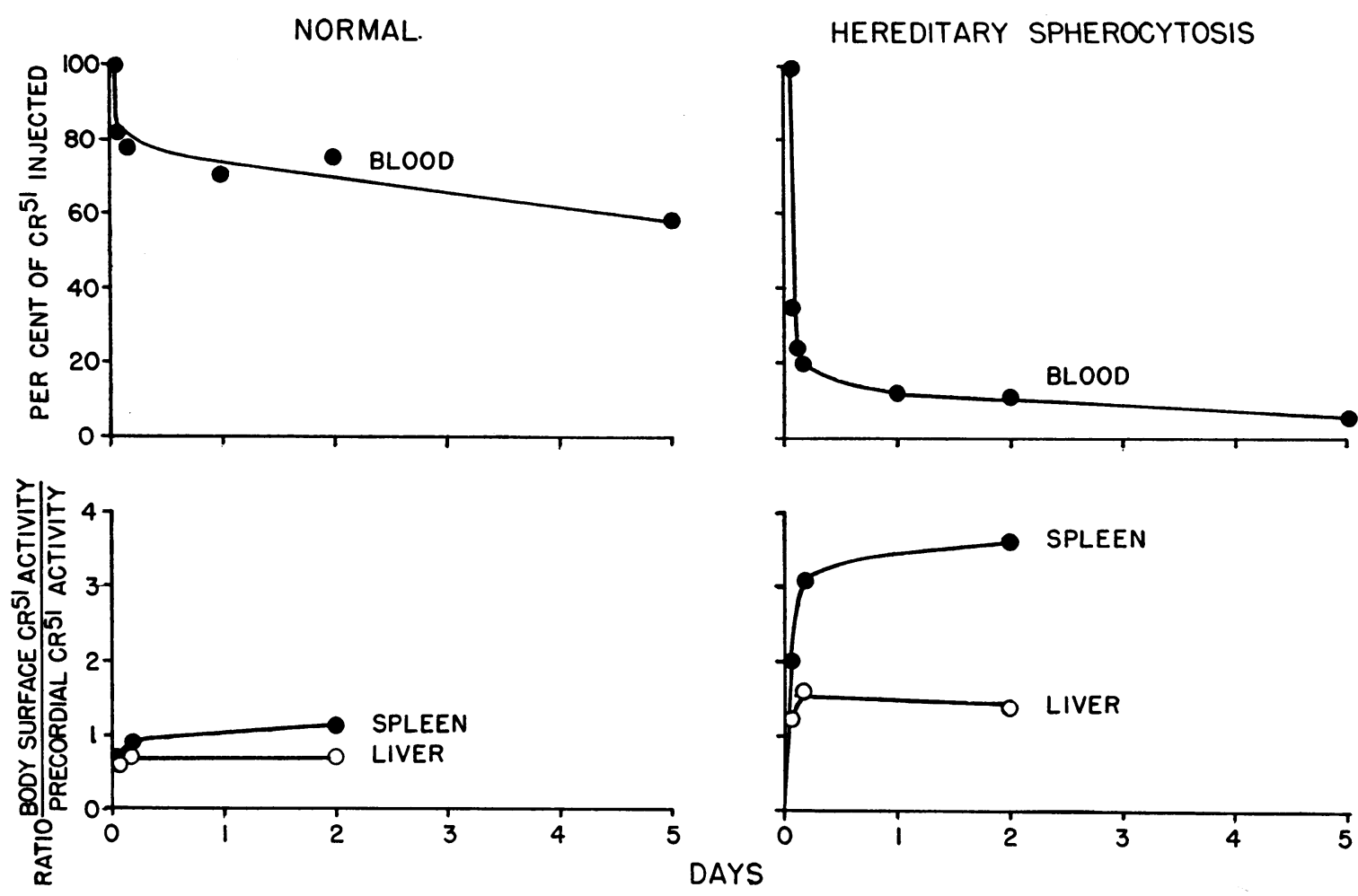

Fig. 1. Comparison of survival (UPPER) AND Sites of SEQuestration (lower) of Normal aND hereditary SPHEROCYTIC (HS) RED BLOOD CElls AFTER GLlCOSE DEPRivation. After their sterile incubation at $37^{\circ} \mathrm{C}$ for 4 hours in a glucose-free medium, hereditary spherocytes (right) manifest markedly decreased viability in vizo compared to normal red cells (left). The removal of these nonviable cells is mainly by the spleen (lower right). The experiment depicted is representative of three performed.

the following formula:

$$
\left[\mathrm{Na}^{24}\right]_{\mathrm{c}}=\frac{\left[\mathrm{Na}^{24}\right]_{\mathrm{w}}-(1-\mathrm{Hct})\left[\mathrm{Na}^{24}\right]_{\mathrm{p}}}{\mathrm{Hct}}
$$

where $\left[\mathrm{Na}^{24}\right]_{\mathrm{c}}=$ cellular $\mathrm{Na}^{24}$ activity, counts per minute per milliliter red cells; $\left[\mathrm{Na}^{24}\right]_{\mathrm{w}}=$ whole cell suspension $\mathrm{Na}^{24}$ activity, counts per minute per milliliter suspension; $\left[\mathrm{Na}^{24}\right]_{\mathrm{p}}=$ "plasma" $\mathrm{Na}^{24}$ activity, counts per minute per milliliter medium; and Hct $=$ hematocrit.

\section{Results}

Metabolic changes accompanying loss of cellular viability

Effect of glucose deprivation. The survival and sites of sequestration of $\mathrm{Cr}^{51}$-labeled HS and normal red cells after their incubation at $37^{\circ} \mathrm{C}$ without agitation for 4 hours in a glucose-free medium are presented in Figure 1. After an initial phase of rapid destruction lasting about 24 hours, approximately $75 \%$ of normal cells were viable (upper left), whereas only $10 \%$ of HS red cells sur- vived this period (upper right). Coincident with the removal of hereditary spherocytes from the circulation a rapid accumulation of radioactivity over the spleen and a slight accumulation over the liver (lower right) occurred. Minimal increases in organ activity were noted in the recipient receiving incubated normal red cells (lower left). To rule out unsuspected serologic incompatibility, washed but unincubated hereditary spherocytes from the same donor were injected at a later date into the same recipient as that in Figure 1. Thirty per cent of the red cells survived the initial 24hour period after injection.

The metabolic characteristics of the red cells depicted in Figure 1 were studied at the time of their injection (Table I). Although destined for rapid splenic removal and destruction, hereditary spherocytes at this time were able to consume glucose even more rapidly than did normal cells. Associated with this increase in glycolysis, HS red cells maintained their levels of reduced GSH more 
TABLE I

Effect of glucose deprivation on normal and hereditary spherocytic $(H S)$ red cells*

\begin{tabular}{lcc}
\hline \hline & Normal & $\begin{array}{c}\text { Hereditary } \\
\text { spherocytosis }\end{array}$ \\
\hline Glucose consumption, $\dagger$ & 1.66 & 2.46 \\
$\mu$ moles/ml cells/hour & 10 & 26 \\
GSH, mg/100 ml cells & 1.9 & 6.1 \\
$\mathrm{Na}^{+}$gain, mEq/L cells & 2.9 & 3.0 \\
$\mathrm{~K}^{+}$loss, mEq/L cells & & \\
\hline
\end{tabular}

* Cells preincubated at $37^{\circ} \mathrm{C}$ for 4 hours in glucose-free media.

$\dagger$ The survival of these cells in vivo is depicted in Figure 1. Their ability to consume glucose was determined during the 4 hours subsequent to this incubation, as described in the text.

effectively. Despite this "hypermetabolism," however, HS red cells were unable to prevent accumulation of intracellular sodium ions; significant increases in cellular $\mathrm{Na}$ content occurred in $\mathrm{HS}$ but not in normal red cells. Cellular $\mathrm{K}^{+}$levels decreased slightly and equally in the two cell suspensions.

Effects of erythrostasis. Duplicate washed suspensions of HS red cells in glucose-containing, buffered albumin media were prepared. One of these was incubated at $37^{\circ} \mathrm{C}$ in a Dubnoff metabolic shaker at 20 cycles per minute; the other was incubated without agitation at the same temperature after a 5 -minute centrifugation at 2,000 rpm. After $3 \frac{1}{2}$ hours both were labeled with $\mathrm{Cr}^{51}$ and injected into compatible normal recipients. Metabolic determinations were performed on samples of the incubated cells at the time of injection. The results are shown in Figure 2 and Table II. HS red cells, after short periods of stagnant incubation (black circles, Figure 2), survived poorly in the circulation (upper, Figure 2) with $27 \%$ undergoing early sequestration, principally in the

TABLE II

Effect of erythrostasis* on $H S$ red cells

\begin{tabular}{cccc}
\hline Cells & $\begin{array}{c}\text { Change in cell } \\
\text { volume }\end{array}$ & $\begin{array}{c}\text { Hemolysis in } \\
\mathbf{0 . 5 0 \%} \mathrm{NaCl}\end{array}$ & $\mathrm{Na}^{+}$gain \\
\hline & $\%$ & $\%$ & $m E q / L$ cells \\
Suspended & 0 & 4.4 & 2.7 \\
Packed & +3.6 & 9.5 & 12.0 \\
\hline
\end{tabular}

* Red cells were incubated 4 hours in glucose-rich medium as described in the text. The above measurements were made at the time of injection into normal recipients, depicted in Figure 2.
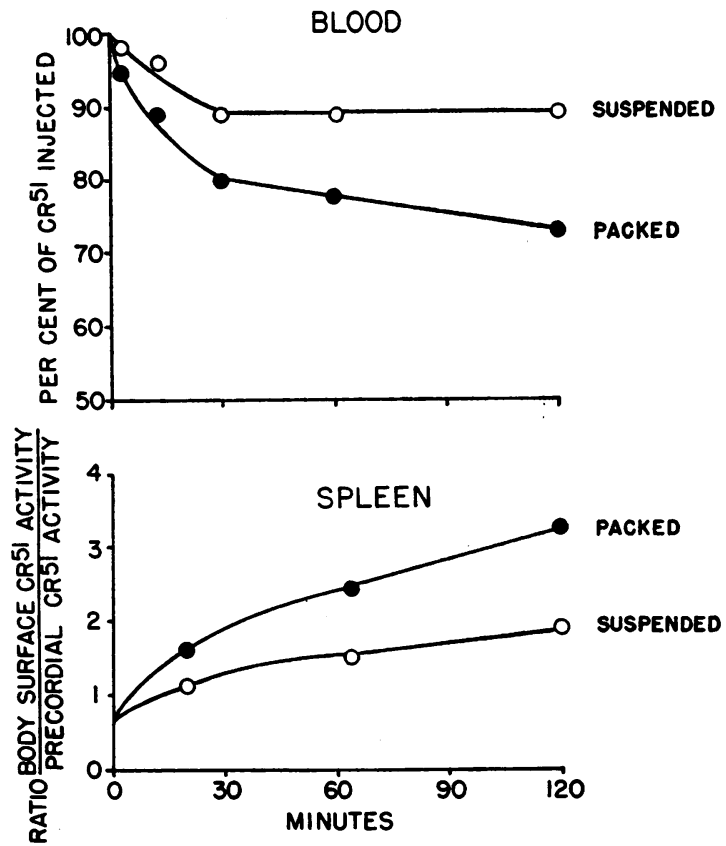

Fig. 2. EFFect of CELL PACKING ON SURVIVAL (UPPER) AND SPLENIC SEQUESTRATION (LOWER) OF INCUBATED HS RED BLOOD CELls. Compared to identical cells that are packed by slow centrifugation (black circles), hereditary spherocytes that are kept suspended by gentle agitation (white circles) during incubation survive better and are trapped by the spleen more slowly (lower). The experiment depicted is representative of two performed.

spleen (lower, Figure 2). Cells that had been gently agitated during their incubation (white circles) survived better, with only $10 \%$ undergoing sequestration. At the time of injection (Table II) the HS red cells that had been subjected to stagnation were slightly swollen, osmotically more fragile, and had increased their intracellular sodium content considerably.

More prolonged incubation was required to render normal cells nonviable under similar conditions. Thus, $100 \%$ of normal red cells incubated with agitation for 24 hours in glucose-rich medium survived normally $\left(\mathrm{Cr}^{51}\right.$-half survival $=$ 26 days); in contrast, only $20 \%$ of normal cells survived beyond the first day in vivo if previously incubated for 24 hours in the packed state. At the time of injection both cell samples were capable of consuming glucose (agitated $=0.96$; spun $=0.24 \mu$ moles per $\mathrm{ml}$ per hour), but only the packed, poorly viable cells had gained intracellular sodium ( $8.8 \mathrm{mEq}$ per L cells). 
TABLE III

Comparison of rates of glycolysis in normal and $H S$ red cells*

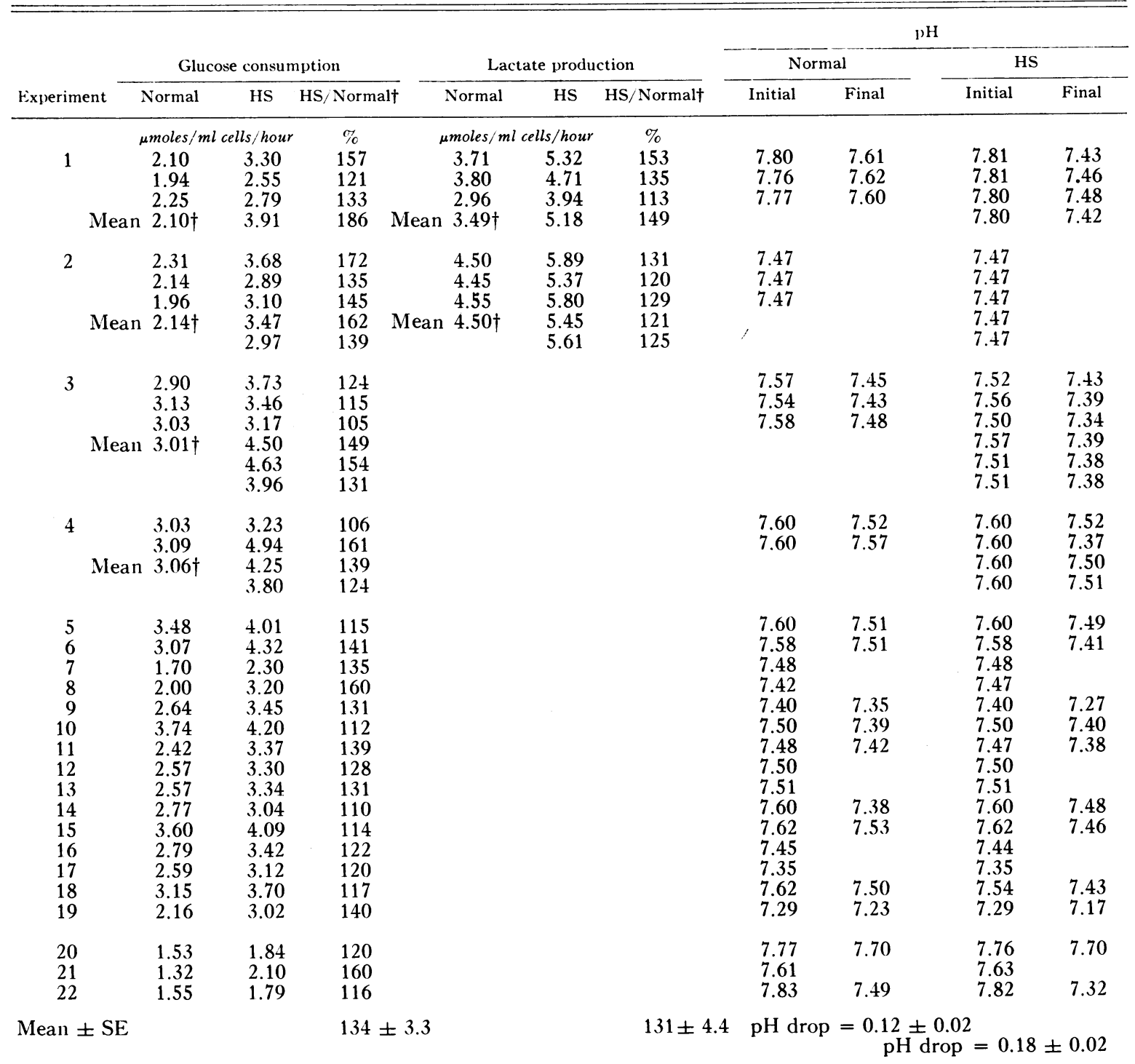

* HS red cells from eight splenectomized patients and normal red cells were washed and simultaneously incubated with agitation for 4 hours at $37^{\circ} \mathrm{C}$ in the same medium. The medium in experiments 1 to 19 was $5 \%$ human albumin as a buffered solution contining $.040 \mathrm{M} \mathrm{PO}_{4}$ and $.022 \mathrm{M}$ glucose (see Methods). Incubations in experiments 20 to 22 were performed in fresh compatible serum containing $.022 \mathrm{M}$ added glucose.

+ Experiments 1 to 4 involved two or more normal control blood specimens. Therefore the glycolytic rates of HS red cells were compared to the mean rate of all normal cells incubated on the same day.

\section{Glycolytic behavior of hereditary spherocytes}

To more fully document the increase in glycolytic rate of hereditary spherocytes, as noted above, the consumption of glucose and formation of lactate by fresh HS red cells from eight splenectomized patients were compared in several experi- ments with those of red cells from numerous normal subjects. Both cell types were washed and incubated in the same medium under nearly identical conditions of $\mathrm{pH}$ and temperature. The results of these studies are shown in Table III. Individual values of glucose consumption and lactate 
TABLE IV

Effect of phosphate concentration on glycolysis in normal and $H S$ red cells*

\begin{tabular}{|c|c|c|c|c|}
\hline \multirow[b]{2}{*}{ Red cells } & & \multicolumn{2}{|c|}{ Glucose consumption } & \multirow[b]{2}{*}{$\begin{array}{l}\text { Stimulation } \\
\text { by high PO, }\end{array}$} \\
\hline & & $\underset{\mathrm{mM}}{\left[\mathrm{PO}_{4}\right]}=1.5$ & $\begin{array}{c}{\left[\mathrm{PO}_{4}\right]=40} \\
\mathrm{mM}\end{array}$ & \\
\hline Normal & $\begin{array}{l}1 \\
2 \\
3 \\
4 \\
5 \\
6 \\
7 \\
8\end{array}$ & $\begin{array}{c}\text { Mmoles } / \mathrm{m} \\
1.32 \\
1.58 \\
1.89 \\
1.92 \\
1.42 \\
1.15 \\
1.47 \\
1.55\end{array}$ & $\begin{array}{c}\text { cells/hour } \\
2.79 \\
3.07 \\
2.57 \\
2.68 \\
2.53 \\
2.42 \\
2.83 \\
2.83\end{array}$ & $\begin{array}{c}\% \\
211 \\
194 \\
136 \\
140 \\
178 \\
210 \\
191 \\
182\end{array}$ \\
\hline $\begin{array}{l}\text { Hereditary } \\
\text { spherocytosis }\end{array}$ & $\begin{array}{l}1 \\
2 \\
3 \\
4 \\
5 \\
6 \\
7\end{array}$ & $\begin{array}{l}2.10 \\
1.55 \\
2.06 \\
2.06 \\
1.85 \\
1.70 \\
1.79\end{array}$ & $\begin{array}{l}\text { Mean }= \\
3.42 \\
3.46 \\
3.30 \\
3.30 \\
3.36 \\
3.62 \\
3.62\end{array}$ & $\begin{array}{c}\text { SE } 180 \pm 10 \\
163 \\
223 \\
160 \\
160 \\
182 \\
213 \\
203\end{array}$ \\
\hline & & & Mean & SE $186 \pm$ \\
\hline
\end{tabular}

* This tabulates a series of experiments in which paired samples of red cells from normal (4) and HS subjects (2) were incubated with agitation for 4 hours at $37^{\circ} \mathrm{C}$ in buffered albumin media (see Methods) of identical $\mathrm{pH}$ and composition except for the $\mathrm{PO}_{4}$ concentration.

production in HS red cells are compared to those in the simultaneously incubated normal cells. Hereditary spherocytes manifested a mean increase in glucose consumption of $34 \%$ and in lactate production of $31 \%$ over normal. Without exception, in 22 consecutive experiments, the glycolytic rate of HS red cells exceeded that of simultaneously incubated normal cells, as determined by both glucose consumption and lactate production $(\mathrm{p}<.001)$. Reflecting the increased lactate production in $\mathrm{HS}$ red cells, the average fall in $\mathrm{pH}$ during the 4-hour incubation period was slightly greater $(p<.05)$ in HS red cells $(-0.18 \mathrm{pH}$

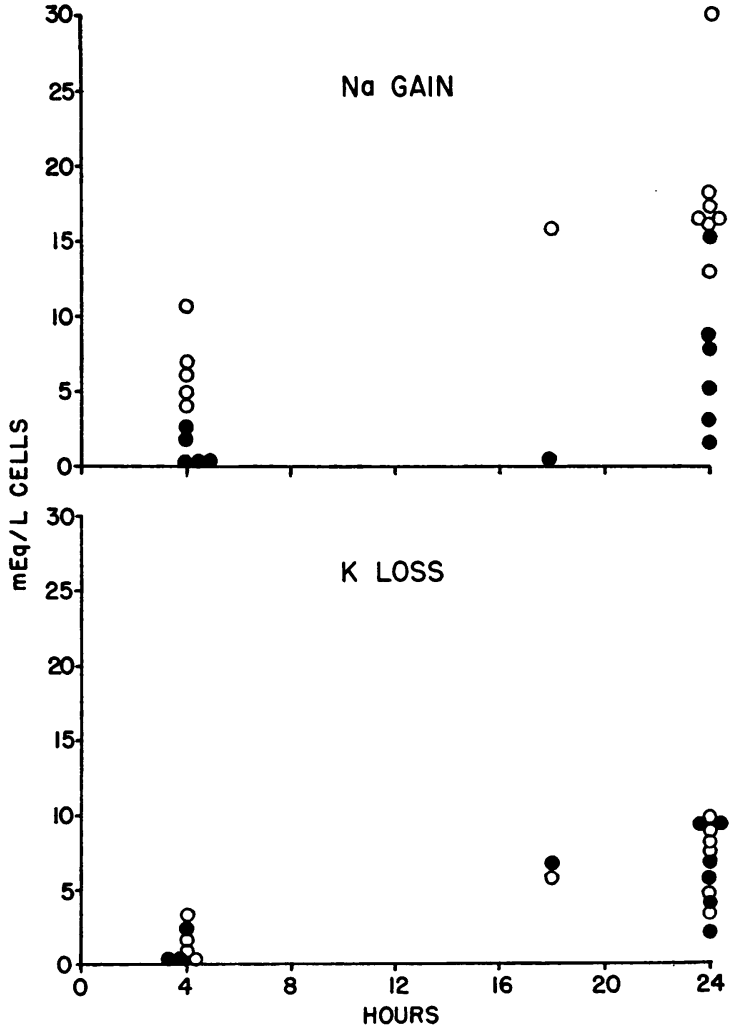

Fig. 3. Comparison of THE EFFECT OF INCUBATION ON THE INTRACEllular NA AND K Levels OF HS AND NORMAL RED BLOOD CELLS. Upon incubation in a glucosecontaining medium, accumulation of intracellular $\mathrm{Na}$ (upper) occurs more rapidly and to a greater degree in hereditary spherocytes (white circles) than in normal red cells incubated simultaneously (black circles). In contrast, $\mathrm{K}$ losses (lower) from both cell types are similar. Each circle represents data from one experiment.

unit) than in normal cells $(-0.12 \mathrm{pH}$ unit), as shown in Table III.

In most of the above studies the concentration of phosphate in the incubation media was $40 \mathrm{mM}$, an amount found by others (38) to promote maximal glycolysis in normal red cells in vitro. At a

TABLE $V$

Activity of hexose monophosphate (HMP) shunt in normal and $H S$ red cells

\begin{tabular}{|c|c|c|c|c|}
\hline Cells & $\begin{array}{c}\text { No. of } \\
\text { incubations }\end{array}$ & $\begin{array}{l}\text { Total glucose } \\
\text { consumption }\end{array}$ & $\begin{array}{l}\text { Conversion } \\
\text { glucose-1-C } \mathrm{C}^{14} \text { to } \mathrm{C}^{14} \mathrm{O}_{2}\end{array}$ & $\begin{array}{l}\text { Glucose metabolized } \\
\text { via HMP shunt* }\end{array}$ \\
\hline Normal & 4 & $\begin{array}{l}\mu m o l e s / \mathrm{ml} \text { cells } / \text { hour } \\
2.55 \pm 0.10 \text { (SD) }\end{array}$ & $\begin{array}{c}\% \\
4.29 \pm 0.07\end{array}$ & 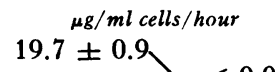 \\
\hline Hereditary spherocytosis & 4 & $3.33 \pm 0.07$ & $2.86 \pm 0.15$ & $17.1 \pm 1.1$ \\
\hline
\end{tabular}

* This value is a minimal approximation of HMP shunt activity, ignoring the contribution by recycling of carbon fragments other than $C^{1}$ through this pathway. 


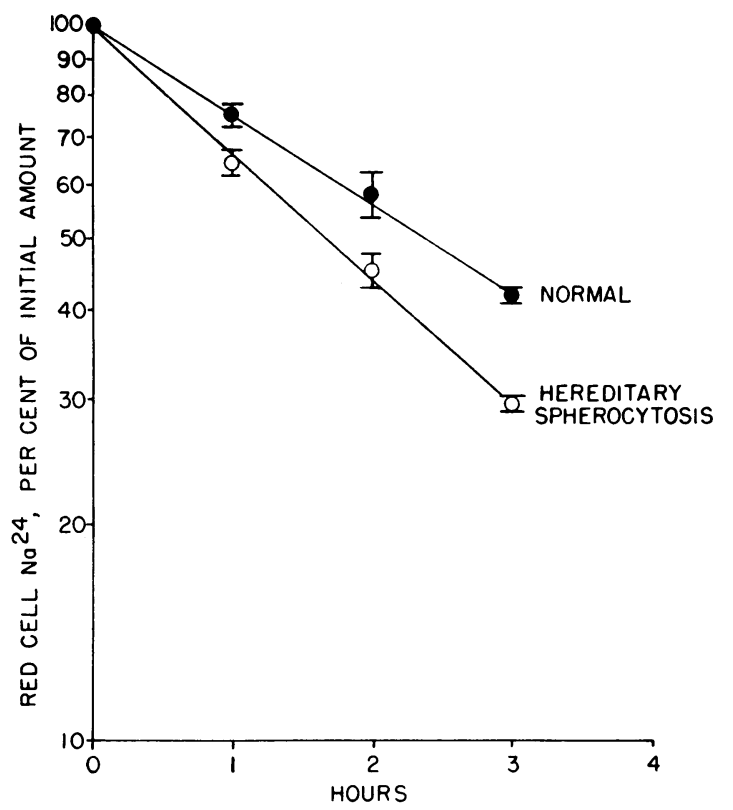

Fig. 4. Comparison of Na efFluX from NORMAL RED CELLS (BLACK CIRCLES) AND HEREDITARY SPHEROCYTES (white CIRCLES). The slopes of the lines derived by the method of least squares indicate that the rate of tracer $\mathrm{Na}^{24}$ extrusion from hereditary spherocytes exceeded that from normal red cells by $34 \%$. Each circle and bracket represents the mean \pm 1 SD of data from five experiments. Red cells from two HS and three normal donors are represented.

more physiologic concentration of $\mathrm{PO}_{4}(1.5 \mathrm{mM})$ the dichotomy in glycolytic rates between normal and HS red cells remained apparent. As shown in Table IV, glucose consumption by both cell types was increased by slightly more than $75 \%$ in $40 \mathrm{mM}$ phosphate as compared with $1.5 \mathrm{mM}$ phosphate. In addition, glycolysis in HS cells was increased above normal in fresh autologous serum (experiments 20 to 22, Table III) as well as in artificial media of $\mathrm{pH}$ levels varying from 6.6 to 8.0 (39).

As shown in Table $\mathrm{V}$, the increased over-all rate of glycolysis in hereditary spherocytes is associated with a significant decrease in both the percentage and absolute quantity of glucose metabolized by the hexose monophosphate (HMP) shunt. Accordingly, the hypermetabolism of HS red cells is entirely through stimulation of the Embden-Meyerhof pathway.

Electrolyte metabolism in hereditary spherocytes. The decreased survival of incubated hereditary spherocytes in vivo was noted above to correlate with their propensity to accumulate intracellular sodium. This was further quantitated as shown in Figure 3. Gains in intracellular $\mathrm{Na}$ by incubated HS red cells (upper, Figure 3 ; white circles) were substantially greater than in normal cells (upper, Figure 3 ; black circles) at all time intervals studied. In contrast the loss of $\mathrm{K}$ from both types of cells was equal (lower, Figure 3 ).

As shown in Figure 4, the hereditary spherocyte, despite its propensity to accumulate intracellular $\mathrm{Na}$, was found to actually transfer $\mathrm{Na}$ from intracellular to extracellular compartments at a more rapid rate than normal, confirming the findings of Harris and Prankerd (19). The initial intracellular $\mathrm{Na}$ concentrations in the two cell types were essentially equal. However, the calculated efflux of $\mathrm{Na}$ from normal cells was $3.7 \mathrm{mEq}$ per $L$ cells per hour, whereas that from hereditary spherocytes was $5.0 \mathrm{mEq}$ per $\mathrm{L}$ cells per hour. ${ }^{8}$

Since efflux of sodium from spherocytes was actually increased, it follows that sodium accumulation by these cells must be secondary to an increased leak of sodium into the cells. Evidence for an abnormal sodium permeability, suggested previously by the tracer $\mathrm{Na}$ studies of Bertles (20), was also observed in the present studies. In our hands, in two experiments, the calculated influx of sodium into HS cells was 4.6 and 4.8 $\mathrm{mEq}$ per L cells per hour, whereas in normal cells, incubated in parallel, sodium influx was 2.3 and $2.6 \mathrm{mEq}$ per $\mathrm{L}$ cells per hour. ${ }^{9}$

8 Sodium efflux was determined by multiplying the fractional decrease in cellular $\mathrm{Na}^{24}$ activity per hour by the total intracellular sodium concentration. This calculation ignores the back flux of isotope from extracellular to intracellular space, which results in a slight underestimation of efflux (40). As evidenced by the acceptable straight-line fit of the data in Figure 4, this error is negligible in the short-term experiments depicted.

9 The discrepancy between the measured $\mathrm{Na}$ influx and efflux of normal red cells is possibly explained by the fact that cells from different normal donors were used in these determinations. Also it is acknowledged that the calculated sodium fluxes in these studies are subject to the following errors: $a$ ) Upon incubation the increased lactate production by HS red cells tends to lower $\mathrm{pH}$ slightly more than in normal cells (Table III). This, in turn, might result in a decreased, and hence underestimation of, $\mathrm{Na}$ flux across $\mathrm{HS}$ cell membranes $(37,41)$. b) The calculation of $\mathrm{Na}$ influx involves the assumption of a "steady state" of constant cellular so- 
The relation of increased sodium transport to increased glycolysis in hereditary spherocytes

Effect of cardiac glycosides. An increase in active transport of sodium out of the cell, necessitated by an increased passive leak of this cation into the cell, should require heightened energy expenditure. The energy for active cation transport is derived from ATP (42-45), the levels of which are maintained by anaerobic glycolysis (2123). An ATPase enzymatic reaction (46-48), which may consist of a series of reactions (49, 50 ), facilitates the release of energy from high energy phosphates for active cation transport; this reaction is partially inhibited by cardiac glycosides such as ouabain $(51,47,48)$. That the hypermetabolism of the HS red cell is related to its increased sodium turnover is shown in Table

TABLE VI

The effect of ouabain on the glucose consumption of normal and HS red cells*

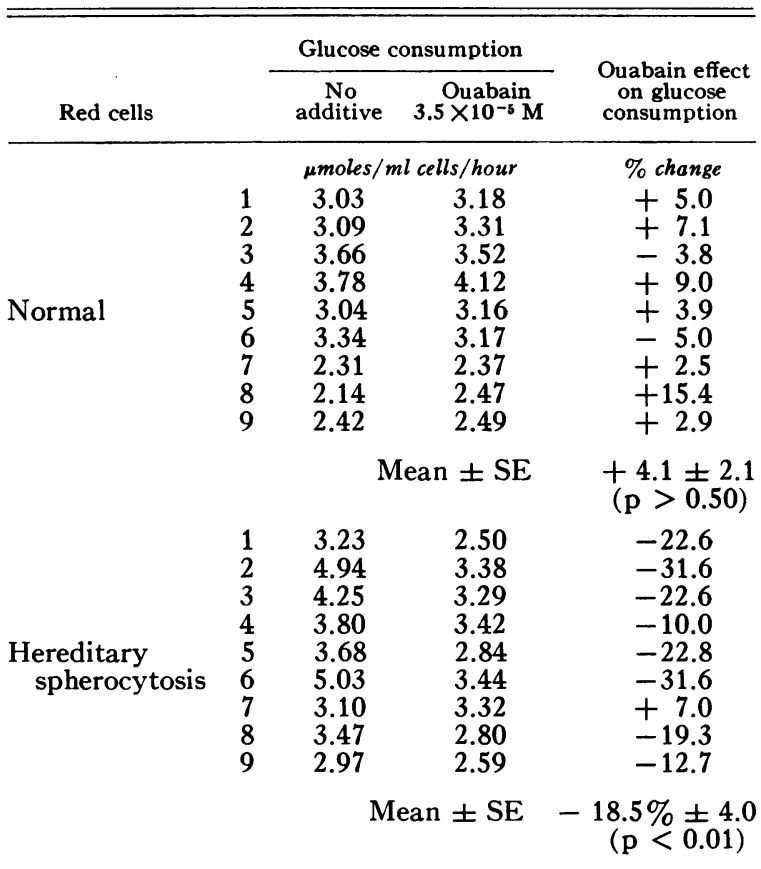

* Two samples of each red cell suspension from seven HS and six normal donors were incubated in parallel with agitation for 4 hours at $37^{\circ} \mathrm{C}$. The suspending medium contained $5 \%$ buffered albumin and $0.022 \mathrm{M}$ glucose (see Methods) with or without added ouabain. The initial $\mathrm{pH}$ of both samples was identical.

dium concentration during analysis $(37,20)$. The slight gains in $\mathrm{Na}$ content in $\mathrm{HS}$ red cells over short periods of incubation (Figure 3) indicate that this assumption may not be strictly true.
TABLE VII

Effect of osmotic swelling on glycolysis of normal red cells*

\begin{tabular}{ccc}
\hline \hline & \multicolumn{2}{c}{ Glucose consumption } \\
\cline { 2 - 3 } Tonicity & No addition & Ouabain $3.5 \times 10^{-5} \mathrm{M}$ \\
\hline $\mathrm{g} / 100 \mathrm{ml} \mathrm{NaCl}$ & \multicolumn{2}{c}{$\mu$ moles $/ 0^{10}$ cells $/$ hour } \\
0.89 (isotonic) & 1.76 & 1.75 \\
0.74 & 1.90 & 1.58 \\
0.66 & 2.12 & 1.66 \\
0.61 & 2.02 & 1.80 \\
0.58 & 2.19 & 1.54 \\
\hline
\end{tabular}

* Two samples of a washed red cell suspension were incubated in parallel with agitation for 4 hours at $37^{\circ} \mathrm{C}$. The suspending media with or without added ouabain were identical in $\mathrm{PO}_{4}$ and glucose concentration and $\mathrm{pH}$. The experiment depicted is representative of two experiments performed.

VI. Whereas the addition of ouabain to normal red cells produced no significant effect on glycolysis $(p>.50)$, its addition to HS red cells led to a significant decrease in glycolytic rate $(p<0.01)$. The average decrease of $18.5 \%$ in the nine experiments depicted is more than half the mean difference in glycolytic rates between $\mathrm{HS}$ and normal red cells (Table III). Indeed, the highly significant difference in glycolytic rate of untreated normal and HS red cells became insignificant during incubation with ouabain $(\mathrm{p}>.40)$.

Normal fresh red cells, whose glucose consumption was unaffected by ouabain, could be altered in vitro so as to become ouabain-sensitive. Suspension of red cells in hypotonic media produces osmotic swelling and increased membrane permeability to a variety of substances (52). Fresh normal red cells were suspended in several nonhemolytic, hypotonic media, and their glucose consumption was measured over the ensuing 4 hours in the presence or absence of ouabain. As seen in Table VII these osmotically swollen cells manifested an increased glycolytic rate compared to the same cells in isotonic medium, and this acceleration of glycolysis was blocked by ouabain.

As seen in Figure 5, sodium levels in normal cells (upper left) are not altered by ouabain during the first 4 hours of incubation in vitro. In addition, ouabain failed to decrease the glycolytic rate of fresh normal red cells (Table VI). In contrast, normal cells injured by incubation for 24 hours manifested further increase in intracellular sodium concentration when exposed to ouabain (Figure 5). In these cells, glucose con- 
sumption was inhibited some $10 \%$ by the glycoside, incubated for short periods, gave evidence of a finding similar to that of Murphy (41). Heredi- utilization of a ouabain-inhibitable sodium transtary spherocytes (right, Figure 5), even when port system. In a 4-hour period of incuba-
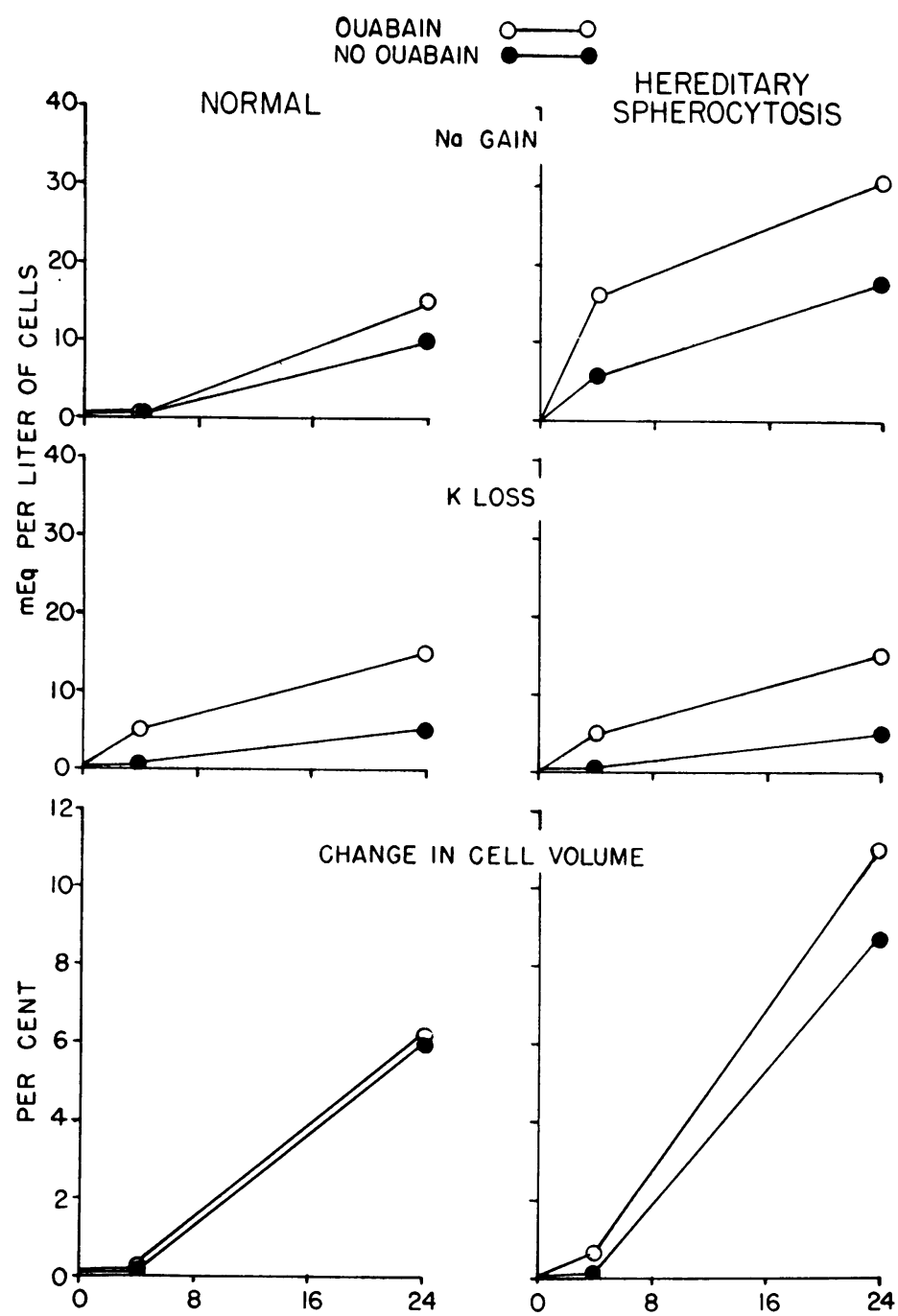

7

VOLUME

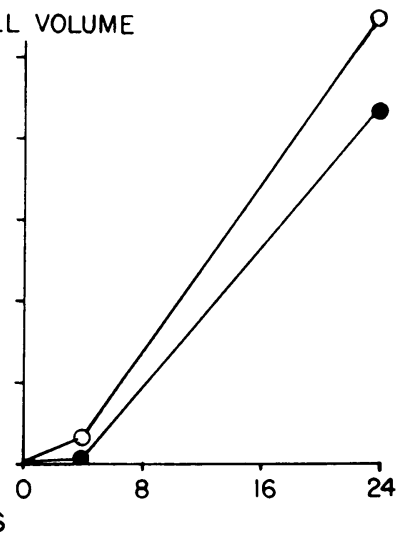

Fig. 5. CoMparison OF THE EFFECT OF OUABAIN ON THE SIZE AND CATION LEVELS OF INCUbated NORMAL ANd HS Red CElls. Hereditary spherocytes accumulate larger amounts of $\mathrm{Na}$ (right upper) when incubated for 4 hours in the presence of ouabain (white circles) than when incubated without ouabain (black circles). In constrast, normal red cells are unaffected by ouabain during this period (left upper). Only with more prolonged incubation of normal cells does ouabain produce a significantly increased $\mathrm{Na}$ gain relative to glycoside-free control cells; this increment is less than in $\mathrm{HS}$ red cells at all time intervals studied. The effect of ouabain on cellular $\mathrm{K}^{+}$levels (middle) is rapid and identical in both cell types. Cellular swelling (lower) during incubation under these conditions was greater in hereditary spherocytes than in normal red cells; ouabain magnifies this difference. Incubations were performed in media containing glucose. The experiment depicted is representative of five performed. 
tion, intracellular sodium levels increased 3-fold in HS red cells exposed to ouabain (top right, Figure 3). This imposed inhibition of sodium transport was associated with a significant decrease in the glycolytic activity of these cells as seen in Table VI. Further evidence that HS cells utilize a ouabain-sensitive ATPase system to a greater degree than do normal cells was obtained by comparing $\mathrm{Na}^{24}$ effluxes in the presence and absence of the glycoside. In normal red cells ouabain inhibited the efflux of $1.8 \mathrm{mEq} \mathrm{Na}$ per L cells per hour, whereas in HS cells, incubated in parallel, ouabain inhibited the efflux of $3.1 \mathrm{mEq} \mathrm{Na}$ per $\mathrm{L}$ cells per hour (not shown). As shown in the middle portion of Figure 5, the effect of ouabain on $\mathrm{K}^{+}$loss was identical in both cell types at all time intervals studied. Red cell swelling (lower, Figure 5), as measured by hematocrit change, paralleled intracellular sodium gain. Thus, during incubation for 24 hours untreated hereditary spherocytes (black circles, right lower) increased their volume $40 \%$ more than did normal cells

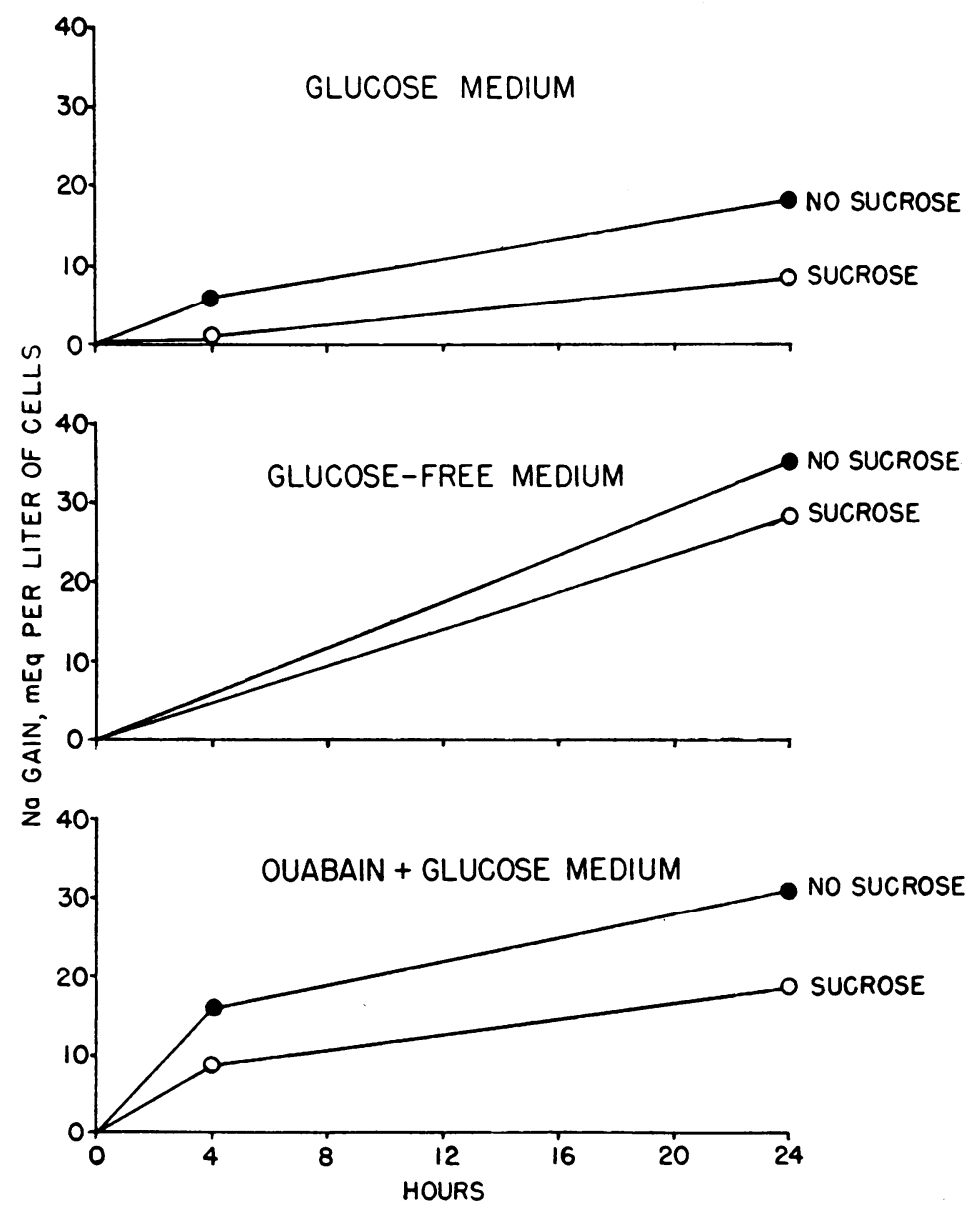

Fig. 6. EFFeCt of EXTRACELlULAR SUCrose on NA ACCUMUlation DURING INCUBATION OF HS RED CELLS. Hereditary spherocytes incubated for short periods (4 hours) in a glucose-replete medium (upper) accumulate significant quantities of intracellular Na. Addition of $80 \mathrm{mM}$ sucrose to the suspending medium prevents this accumulation. The protective effect of sucrose continues over more prolonged periods and is apparent in red cells whose $\mathrm{Na}$ pumping mechanism is inhibited as by their suspension in a glucose-free medium (middle) or in a glucose medium containing $3.5 \times 10^{-5} \mathrm{M}$ ouabain (lower). The experiment depicted in the upper portion is representative of ten performed. The middle and lower portions depict single experiments. 


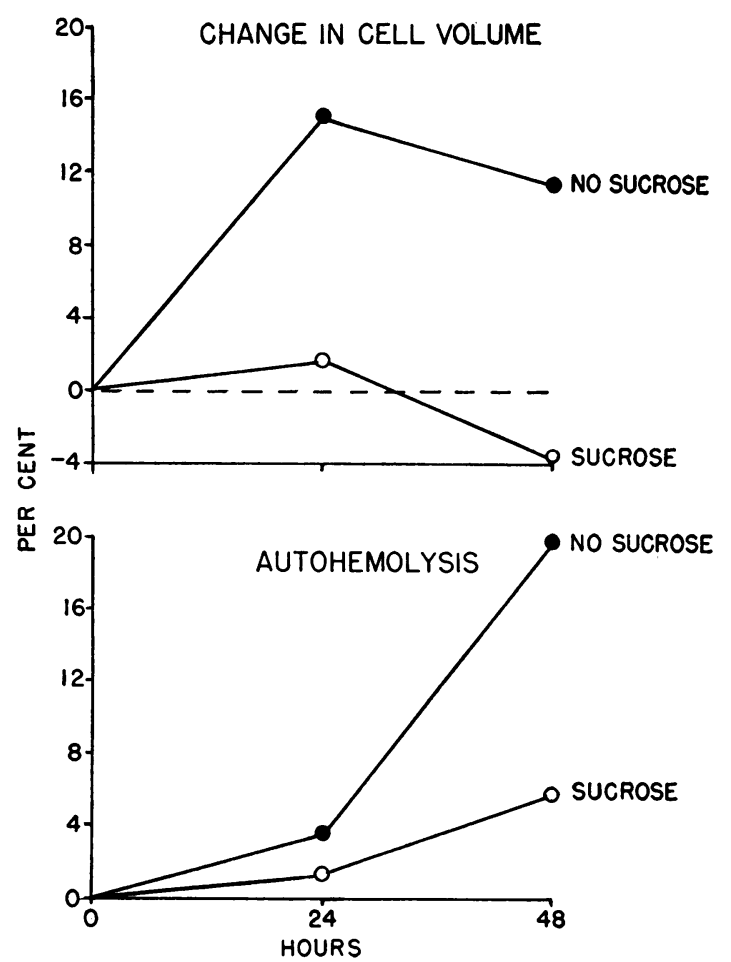

Fig. 7. EfFects of extracellular sucrose on the CELL VOLUME AND AUTOHEMOLYSIS OF INCUBATED HS RED CELLS. Over the first 24 hours hereditary spherocytes incubated in glucose-free medium swell appreciably. The addition of $80 \mathrm{mM}$ sucrose to the medium (white circles, upper) inhibits this process throughout the 48-hour period of incubation. In addition, by inhibiting osmotic swelling, sucrose prevents the abnormal autohemolysis of HS red cells that are incubated for prolonged periods (lower). The levels of autohemolysis of HS red cells suspended in a sucrose medium fall within the normal range (not shown). The experiment depicted is representative of two performed.

(black circles, left lower). Ouabain accentuated this difference and after more prolonged incubation produced increased autohemolysis in HS cells as well (not shown).

Effect of sucrose. Reasoning from the fact that the permeability of red cells is increased in hypotonic solutions, an attempt was made to decrease the permeability of hereditary spherocytes to $\mathrm{Na}$ by suspending them in the usual incubation medium rendered hypertonic by the addition of 80 $\mathrm{mM}$ sucrose. This substance is impermeable, but osmotically active. The effect of such suspension on the sodium levels of HS red cells is shown in Figure 6. In actively metabolizing spherocytes (top portion), sucrose addition (white circles) completely prevented the usual sodium gain observed over the first 4 hours of incubation. At the end of 24 hours, the sucrose-treated red cells had gained only one-half the quantity of sodium as did untreated cells. Normal cells were similarly protected from sodium accumulation during prolonged incubation (not shown). To elucidate the mechanism of this protective effect, spherocytes were suspended in either glucose-free (middle) or ouabainized media (lower) to inhibit active sodium efflux from the incubated red cells. In both media sucrose inhibited cellular sodium gain. These results support the conclusion that this substance produces a diminished influx of sodium into these red cells, either by diminishing membrane permeability per se or by decreasing the gradient of $\mathrm{Na}$ across the red cell membrane. Coincident with its inhibition of cellular sodium accumulation, sucrose diminished markedly the swelling and autohemolysis of HS red cells incubated for prolonged periods in the absence of glucose (Figure $7)$. Thus, the presence of sucrose in the incubation medium reduced swelling of HS red cells during the first 24 hours by 10 -fold (upper). The hematocrit change recorded with sucrose in Figure 7 compares cell size immediately after sucrose addition with that following incubation. The cell shrinkage that ordinarily occurs between 24 and 48 hours of incubation, as noted previously by Selwyn and Dacie (6), occurred at a slightly greater rate with added sucrose. Correlated with its inhibition of cellular swelling, sucrose decreased the autohemolysis, characteristic of HS cells, by two-thirds-to within the normal range (lower, Figure 7).

TABLE VIII

Effect of sucrose on the metabolism of HS red cells*

\begin{tabular}{lcc}
\hline & \multicolumn{2}{c}{ Medium } \\
\cline { 2 - 3 } & No sucrose & Sucrose† \\
\hline Glucose consumption, & 3.45 & 3.89 \\
$\mu$ moles/ml cells/hour & 56 & 55 \\
GSH, mg/100 ml cells & 56 & 0 \\
Na gain, mEq/L cells & 4.9 & 3.1 \\
K loss, mEq/L cells & 0.7 &
\end{tabular}

* Cells were incubated at $37^{\circ} \mathrm{C}$ for 4 hours in glucosecontaining media either with or without sucrose added to a final $80 \mathrm{mM}$ concentration. The survival of these cells in vivo is depicted in Figure 8.

$\dagger$ All values are expressed per original volume of red cells before their suspension in sucrose. 
In addition to its protective effects in vitro, sucrose was found to maintain the viability of incubated spherocytes as determined subsequently in vivo. As shown in the top portion of Figure 8, HS red cells incubated for 4 hours in vitro survived longer if incubated in the presence of sucrose (white circles) than in its absence (black circles). Splenic sequestration of these treated cells (lower) was correspondingly decreased. Measurements of metabolic activity of these cells at the time of injection are given in Table VIII. Most significant was the correlation between enhanced survival of sucrose-suspended HS red cells (Figure 8 ) and the absence of sodium accumulation in these cells.

Further evidence that the diminished viability of incubated HS red cells relates to their propensity to accumulate $\mathrm{Na}$ is shown in Table IX. Parallel incubations of $\mathrm{HS}$ and normal red cells were made in media of identical composition except for their concentrations of $\mathrm{Na}$. A low-Na medium was prepared by replacing sodium chloride with an equimolar quantity of choline chloride so that the final extracellular $\mathrm{Na}$ concentration was $11 \mathrm{mEq}$ per $\mathrm{L}$. This concentration approximates intracellular $\mathrm{Na}$ levels, and thus a net movement of $\mathrm{Na}$ into the cells was inhibited. As shown in Table IX, for the first 24 hours of incubation swelling of both normal and HS red cells was completely inhibited in this medium; concomitantly autohemolysis of HS cells after 48 hours was diminished.

TABLE IX

Effect of Na concentration of the suspending medium on the swelling and autohemolysis of red blood cells

\begin{tabular}{cccc}
\hline \multirow{2}{*}{ Cells } & Medium* & $\begin{array}{c}\text { Hematocrit } \\
\text { increase }\end{array}$ & Autohemolysis \\
\hline \multirow{3}{*}{ Normal } & & $\% / 24$ hrs & $\% / 48$ hrs \\
& High Na & 6.0 & 0.23 \\
Hereditary & Low Na & 0 & 0.24 \\
spherocytosis & High Na & 8.6 & 5.5 \\
& Low Na & 0 & 2.5
\end{tabular}

* The red cell suspensions were incubated at $37^{\circ} \mathrm{C}$ in isotonic media of the following cation concentrations: low $\mathrm{Na}-[\mathrm{Na}]=11 \mathrm{mEq} / \mathrm{L},[\mathrm{K}]=4.7 \mathrm{mEq} / \mathrm{L}$, [choline $]=134 \mathrm{mM}$, and $\mathrm{pH}=7.3$; high $\mathrm{Na}-[\mathrm{Na}]=145$ $\mathrm{mEq} / \mathrm{L},[\mathrm{K}]=4.7 \mathrm{mEq} / \mathrm{L}$, and $\mathrm{pH}=7.3$. Both media contained initially $22 \mathrm{mM}$ glucose. In the absence of glucose choline produces increased autohemolysis in both cell types (39). The experiment depicted is representative of two performed.
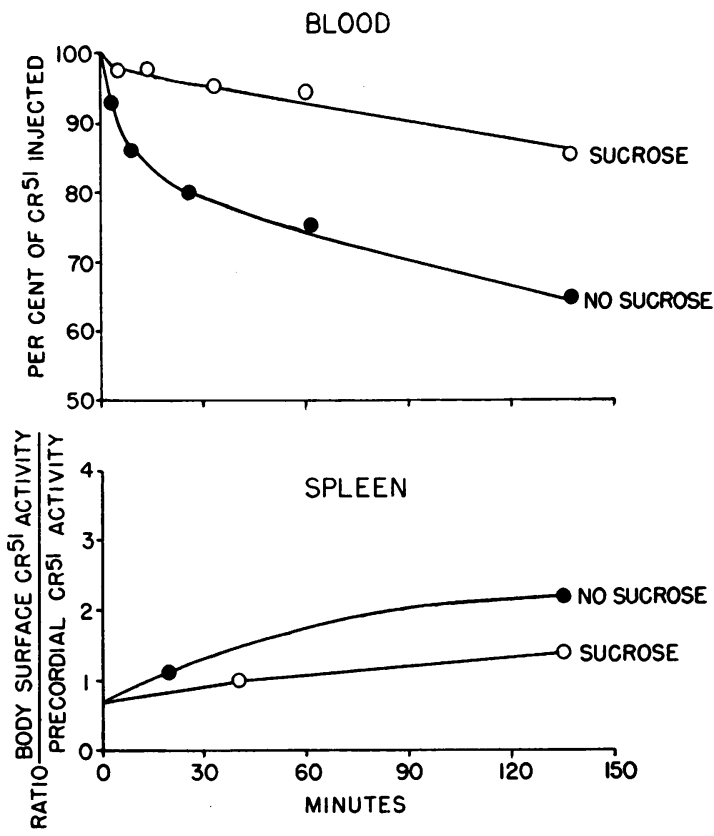

Fig. 8. EFfect of incubation in SUCrose on the SUBSEQUENT SURVIVAL IN VIVO AND SPLENIC REMOVAL OF HS RED CELLS. The survival of hereditary spherocytes injected after a 4-hour incubation in the presence of 80 $\mathrm{mM}$ sucrose is significantly greater than that of identical cells incubated without sucrose (upper). Reflecting this enhancement in survival, removal of these cells by the spleen occurs at a slower rate (lower). The experiment depicted is representative of two performed.

\section{Discussion}

The present studies suggest that of primary importance in the pathogenesis of hereditary spherocytosis is an inherent increase in sodium permeability of the red cell membrane. The total intracellular sodium concentration of $\mathrm{HS}$ red cells, sampled directly from the circulation, is normal (6). Presumably, therefore, circulating HS red cells compensate for an increased leak of sodium by means of active pumping mechanisms. The expenditure of energy to support this compensation must come ultimately from glucose utilization (21-23) and more specifically through an increased regeneration of ATP $(42-45)$. When these cells are deprived of glucose for short periods in vitro, they rapidly gain sodium, and they lose viability as judged by their subsequent survival in vivo. If removed from glucose for longer periods, the intake of sodium (and water) continues, leading to cellular swelling, a further gen- 
eral increase in membrane permeability, and ultimately to autohemolysis. Although more striking in the absence of glucose, these changes were found to occur even in the presence of adequate glucose if HS red cells were allowed to undergo packing. By analogy, red cells subjected to hemoconcentration and erythrostasis in the spleen sinusoids are probably unable to meet their increased sodium transport requirements, thereby initiating the lethal sequence described above.

The relation of abnormal sodium permeability to decreased survival of hereditary spherocytes. A close correlation appears to exist between decreased survival of red cells in vivo and cellular sodium accumulation in vitro. Thus, sucrose decreases the $\mathrm{Na}$ influx of red cells (37) and in our hands inhibited thereby the sodium gain of incubated hereditary spherocytes; concomitantly red cell survival in vivo was enhanced. Conversely, red cells that have been exposed to sulfhydryl inhibitors were found to manifest both increased cation permeability (33) and an extraordinary liability to splenic sequestration $(53,54)$. The integrity of cells so altered was also preserved by impermeable osmotic agents such as sucrose (33).

The fact that excessive autohemolysis occurs in HS cells at a time when red cell volume is diminishing (24 to 48 hours) has led to the view that gross degeneration or dissolution of the cell membrane underlies this phenomenon. That suspension media of moderate sucrose, or low $\mathrm{Na}$, concentrations prevent the excessive autohemolysis of these cells indicates rather that this hemolysis is principally osmotic in nature. Any decrease, however, in surface area of the incubated cells, as by losses of structural lipids $(17,18)$ would potentiate the lytic effect of osmotic cell swelling.

The mechanisms by which the hereditary spherocyte compensates for increased membrane permeability. Under optimal conditions, namely free suspension in a glucose-containing medium such as circulating plasma, the HS red cell compensates well for the increase in sodium influx across its membrane. The mechanism by which this compensation occurs is probably as follows: A tendency to gain intracellular sodium ion by increased influx serves to stimulate membrane ATPase $(55,56)$. This in turn facilitates release of energy stored as ATP, enhancing thereby the ac- tive extrusion of sodium from the cell. Possibly the reported increased susceptibility of HS cells to injury by fluoride (57) or by EDTA (58) reflects the special dependence of these cells on the $\mathrm{Mg}^{++}$-requiring ATPase system.

The stimulation of glucose consumption by increased sodium transport in the hereditary spherocyte. In the present studies glycolytic rates of red cells were measured over a 4-hour period during which time the $\mathrm{pH}$ of suspensions fell slightly. This fall in $\mathrm{pH}$ was generally greater in HS than in normal red cells (Table III). A lower $\mathrm{pH}$ inhibits glycolysis $(38,59,39)$. Thus increased lactate accumulation in HS cells must have tended to diminish the increased glycolysis actually observed. Glycolysis in red cells is also affected by variations in oxygen tension (59). HS red cells consumed glucose more rapidly than normal whether under 95\% oxygen (experiments 1 to 19, Table III) or $20 \%$ oxygen (experiments 20 to 22, Table III).

Part of the hypermetabolism of HS red cells can be shown to be intimately related to the increased sodium turnover manifested by these cells. Thus, the inhibition of membrane ATPase, and hence the depression of active cation transport, by incubation of red cells in ouabain-containing (51) media significantly reduced the consumption of glucose by HS but not by normal red cells. With such treatment the glycolytic rate of HS cells no longer significantly differed from that of normal cells.

The increment in glucose consumption necessary to provide energy for the increased requirements of sodium transport in HS red cells can be computed. The unidirectional sodium flux across normal red cell membranes is roughly $3 \mathrm{mEq}$ per $\mathrm{L}$ cells per hour, a figure reported by Solomon (37) and confirmed by Glynn (60). In HS cells sodium flux approximates $5 \mathrm{mEq}$ per L cells per hour as reported by Harris and Prankerd (19) and Bertles (20) and confirmed in the present studies. By use of red cell ghost preparations, Sen and Post (61) as well as Glynn (56) have demonstrated that $3 \mathrm{mEq}$ of sodium is actively transported for every milliequivalent of phosphate produced by the ouabain-sensitive ATPase reaction. Since the increment in sodium transported by HS red cells is $2 \mathrm{mEq}$ per L cells per hour, an additional $\frac{2}{3}$ mmole of ATP per L HS cells 
per hour must be utilized. This increment would be produced by the metabolism of $\frac{1}{3}$ mmole of glucose over the Embden-Meyerhof pathway. In our hands glucose consumption of normal cells averages 2 mmoles per $\mathrm{L}$ cells per hour. An additional $\frac{1}{3}$ mmole in this consumption would represent a $16 \%$ increase over that of normal. This figure is in agreement with the observation that ouabain reduced glycolysis by $18 \%$ in $\mathrm{HS}$ cells (Table VI). The increase in glycolysis in the hereditary spherocyte can therefore be inferred to be dependent in large part on membrane ATPase activity.

Only about half of the ATPase activity of the red cell membrane is sensitive to ouabain $(47,48)$. Previous studies of this portion have utilized red cell ghosts $(47,48)$, or red cells injured by prolonged storage (47), in each case involving pathologic accumulations of intracellular sodium. That ouabain has a minimal effect upon fresh normal red cells, but a marked effect on HS cells, indicates that this ouabain-sensitive ATPase is stimulated in the former cells by acquired membrane injury but in the latter cells by an inherent abnormality in membrane function. Gabrio, Finch, and Huennekens (62) have similarly suggested from unpublished data that ATPase is in a "latent state" in viable cells but becomes more active as the cell deteriorates.

The products of the reaction catalyzed by ATPase, namely ADP and inorganic phosphate (Pi), have both been found to stimulate the consumption of glucose in subcellular (63) as well as intact cell systems (64). In addition, both have been proposed as regulators of glycolysis in intact red cells $(38,65)$. A direct link, therefore, is suggested between sodium-induced activation of ATPase and hypermetabolism in HS red cells. Thus the increased rate of degradation of ATP stimulated by increased sodium influx provides both energy for increased cation transport, and by its products stimulates glycolysis as well. The reports of abnormally rapid ATP depletion with associated ADP and $\mathrm{Pi}$ accumulation in $\mathrm{HS}$ red cells incubated in vitro (66) or entrapped in splenic sinusoids (17) are consistent with an increased ATPase activity of these cells, as is the finding (8) of increased inorganic phosphate and decreased ATP labeling in spherocytes incubated with $\mathrm{P}^{32}$. The fact that the Embden-Meyerhof pathway, and not the HMP shunt, was accelerated in HS cells (Table V) is also consistent with this explanation, for the Embden-Meyerhof pathway is solely responsible for ATP regeneration in the red cell. The high hemoglobin concentration and proportionately low cellular water content of HS red cells (6) remains a puzzling and unexplained phenomenon. Its possible relationship to enhanced phosphorolysis of ATP in these cells is currently under study.

The role of the spleen. Those HS red cells that initially escape splenic destruction are nevertheless slowed in transit (67) and gradually become more spheroidal with repeated passages through the spleen (68). This cumulative splenic "conditioning" (17) of cells repeatedly detained and released produces a population of markedly fragile cells destined for permanent trapping and destruction in the spleen. When the red cell tarries in the spleen sinusoids, it is presumably subjected to a number of stresses that might impair metabolic activity. These metabolic stresses include: 1) an impaired diffusion of metabolites and 2) competition for metabolites from surrounding tissue (reticuloendothelial) cells. The first effect, which is mimicked by producing erythrostasis in vitro, produces rapid damage by depleting the red cell of glucose, since the red cell lacks appreciable energy stores. In addition, lactic acid will accumulate while glycolysis lasts, lowering the intracellular $\mathrm{pH}$ and thereby inhibiting anaerobic glycolysis further $(59,38)$. Indeed, recent studies (69) have shown that intracellular $\mathrm{pH}$ is abnormally low in HS cells before but not after splenectomy. Undoubtedly these deleterious processes are greatly speeded when the red cells are closely approximated to metabolically active tissue cells within stagnant sinusoids or cords.

The metabolic stresses of erythrostasis are gradually lethal to normal red cells. HS red cells suffer double jeopardy by virtue of the fact that their increased permeability to sodium necessitates, for continued homeostasis, a sustained, accelerated glycolysis. As with the Red Queen (70), this red cell must perforce "do all the running it can do, to keep in the same place." 


\section{Summary}

The effects of erythrostasis on the metabolism of normal and hereditary spherocytic (HS) red cells were correlated with effects on their viability when transfused into normal subjects. The red cells of splenectomized HS patients lost viability rapidly when packed or when deprived of glucose. Surprisingly, HS red cells consumed glucose faster than normal, through acceleration of the Embden-Meyerhof pathway, even as they lost viability.

Correlated with their rapid loss of viability, HS cells accumulated more sodium than normal during incubation. Tracer $\mathrm{Na}^{24}$ influx into spherocytes was increased roughly two-thirds over that in normal red cells, and extrusion of $\mathrm{Na}^{24}$ by active transport was similarly increased. Inhibition of active cation transport by ouabain diminished glycolysis toward normal levels in fresh HS red cells without affecting fresh normal red cells. Contrasted to normal cells, HS red cells rapidly accumulated sodium and lost viability on exposure to ouabain.

The addition to the suspending medium of impermeable, osmotically active substances, such as sucrose, diminished the influx and accumulation of sodium by hereditary spherocytes during erythrostasis. Osmotic swelling was thereby reduced, in vivo survival prolonged, and the marked autohemolysis characteristic of incubated HS red cells was prevented. Thus, the autohemolysis of $\mathrm{HS}$ red cells is essentially a form of osmotic lysis.

These findings indicate that the hemolysis of HS red cells is associated with "overwork" rather than with a deficiency in energy metabolism. The following sequence is proposed: 1) The primary defect of the HS red cell resides in the membrane, which is abnormally permeable to sodium; 2) the heightened influx of sodium stimulates active sodium extrusion from the cell by arousing a usually latent ATPase system ; 3) the resulting increased breakdown of ATP provides not only energy for cation transport, but also liberates ADP and inorganic phosphate, which in turn stimulate glycolysis. Under optimal conditions, as in the general circulation, these compensatory mechanisms suffice. During metabolic stress, as is believed to occur in the spleen, sodium accumulates intracellularly, and irreversible changes in membrane permeability and ultimately hemolysis ensue.

\section{Acknowledgment}

We gratefully acknowledge the cooperation of Dr. Gerald W. Hazard and the advice of Dr. Laurence E. Earley in these studies.

\section{References}

1. Jandl, J. H. Hereditary spherocytosis in The Metabolic Basis of Inherited Disease, J. B. Stanbury, J. B. Wyngaarden, and D. S. Fredrickson, Eds. New York, McGraw-Hill, 1960, p. 1015.

2. De Gruchy, G. C. Red-cell metabolism: fundamental and clinical aspects. Aust. Ann. Med. 1960, 9, 237.

3. Carson, P. E., and A. R. Tarlov. Biochemistry of hemolysis. Ann. Rev. Med. 1962, 13, 105.

4. Emerson, C. P., Jr., S. C. Shen, T. H. Ham, E. M. Fleming, and W. B. Castle. Studies on the destruction of red blood cells. IX. Quantitative methods for determining the osmotic and mechanical fragility of red cells in the peripheral blood and splenic pulp; the mechanism of increased hemolysis in hereditary spherocytosis (congenital hemolytic jaundice) as related to the functions of the spleen. Arch. intern. Med. 1956, 97, 1.

5. Young, L. E., M. J. Izzo, and R. F. Platzer. Hereditary spherocytosis. I. Clinical, hematologic and genetic features in 28 cases, with particular reference to the osmotic and mechanical fragility of incubated erythrocytes. Blood 1951, 6, 1073.

6. Selwyn, J. G., and J. V. Dacie. Autohemolysis and other changes resulting from the incubation in vitro of red cells from patients with congenital hemolytic anemia. Blood 1954, 9, 414.

7. Dacie, J. V. The Haemolytic Anaemias, Congenital and Acquired: Part I. The Congenital Anaemias, 2nd ed. New York, Grune \& Stratton, 1960.

8. Prankerd, T. A. J., K. I. Altman, and L. E. Young. Abnormalities of carbohydrate metabolism of red cells in hereditary spherocytosis. J. clin. Invest. 1955, 34, 1268.

9. Shafer, A. W. Glycolytic intermediates of erythrocytes in hereditary spherocytosis (abstract). Clin. Res. 1961, 9, 67.

10. Zipursky, A., D. Mayman, and L. G. Israels. Phosphate metabolism in erythrocytes of normal humans and of patients with hereditary spherocytosis. Canad. J. Biochem. 1962, 40, 95.

11. Prankerd, T. A. J. Inborn errors of metabolism in red cells of congenital hemolytic anemias. Amer. J. Med. 1957, 22, 724.

12. Dunn, I., K. H. Ibsen, E. L. Coe, A. S. Schneider, and I. M. Weinstein. Erythrocyte carbohydrate metabolism in hereditary spherocytosis. J. clin. Invest. 1963, 42, 1535. 
13. Allison, A. C., M. Kates, and A. T. James. An abnormality of blood lipids in hereditary spherocytosis. Brit. med. J. 1960, 2, 1766.

14. Kates, M., A. C. Allison, and A. T. James. Phosphatides of human blood cells and their role in spherocytosis. Biochim. biophys. Acta (Amst.) 1961, 48, 571.

15. De Gier, J., L. L. M. Van Deenen, R. A. Geerdink, K. Punt, and M. C. Verloop. Phosphatide patterns of normal, spherocytic and elliptocytic red blood cells. Biochim. biophys. Acta (Amst.) 1961, 50, 383.

16. Philips, G. B., and N. S. Roome. Quantitative chromatographic analysis of the phospholipids of abnormal human red blood cells. Proc. Soc. exp. Biol. (N. Y.) 1962, 109, 360.

17. Prankerd, T. A. J. Studies on the pathogenesis of haemolysis in hereditary spherocytosis. Quart. J. Med. 1960, 29, 199.

18. Reed, C. F., and S. N. Swisher. Abnormalities of in vitro behavior of structural lipids of red blood cells from patients with hereditary spherocytosis. J. clin. Invest. 1960, 39, 1019.

19. Harris, E. J., and T. A. J. Prankerd. The rate of sodium extrusion from human erythrocytes. J. Physiol. (Lond.) 1953, 121, 470.

20. Bertles, J. F. Sodium transport across the surface membrane of red blood cells in hereditary spherocytosis. J. clin. Invest. 1957, 36, 816.

21. Danowski, T. S. The transfer of potassium across the human blood cell membrane. J. biol. Chem. 1941, 139, 693.

22. Harris, J. E. The influence of the metabolism of human erythrocytes on their potassium content. J. biol. Chem. 1941, 141, 579.

23. Maizels, M. Cation control in human erythrocytes. J. Physiol. (Lond.) 1949, 108, 247.

24. Jacob, H. S., and J. H. Jandl. Cellular permeability in the pathogenesis of hereditary spherocytosis (abstract). J. clin. Invest. 1963, 42, 944 .

25. Ham, T. H. A Syllabus of Laboratory Examinations in Clinical Diagnosis. Critical Evaluation of Laboratory Procedures in the Study of the $\mathrm{Pa}$ tient, revised edition, L. B. Page and P. J. Culver, Eds. Cambridge, Harvard University Press, 1960.

26. Bergenhem, B., and R. Fahraeus. Über spontane Häemolysinbildung im Blut. Z. ges. exp. Med. 1936, 97, 555.

27. Collier, H. B. and K. M. Wilbur. Lysolecithin and the antihemolytic value of the blood. J. Lab. clin. Med. 1944, 29, 1123.

28. Murphy, J. R. Erythrocyte metabolism. III. Relationship of energy metabolism and serum factors to the osmotic fragility following incubation. J. Lab. clin. Med. 1962, 60, 86.

29. Jandl, J. H., M. S. Greenberg, R. H. Yonemoto, and W. B. Castle. Clinical determination of the sites of red cell sequestration in hemolytic anemias. J. clin. Invest. 1956, 35, 842.
30. Furth, F. W. Effect of spherocytosis on volume of trapped plasma in red cell column of capillary and Wintrobe hematocrits. J. Lab. clin. Med. 1956, 48, 421.

31. Scholz, R., H. Schmitz, Th. Bücher, and J. O. Lampen. Uber die Wirkung von Nystatin auf Bäckerhefe. Biochem. Z. 1959, 331, 71.

32. Nelson, N. A photometric adaptation of the Somogyi method for the determination of glucose. J. biol. Chem. 1944, 153, 375.

33. Jacob, H. S., and J. H. Jandl. Effects of sulfhydryl inhibition on red blood cells. I. Mechanism of hemolysis. J. clin. Invest. 1962, 41, 779.

34. Grunert, R. R., and P. H. Phillips. A modification of the nitroprusside method of analysis for glutathione. Arch. Biochem. 1951, 30, 217.

35. Beutler, E. The glutathione instability of drugsensitive red cells. A new method for the in vitro detection of drug sensitivity. J. Lab. clin. Med. 1957, 49, 84.

36. Goodner, C. J., and N. Freinkel. Studies of anterior pituitary tissue in vitro: Effects of insulin and experimental diabetes mellitus upon carbohydrate metabolism. J. clin. Invest. 1961, 40, 261.

37. Solomon, A. K. The permeability of the human erythrocyte to sodium and potassium. J. gen. Physiol. 1952, 36, 57.

38. Chapman, R. G., M. A. Hennessey, A. M. Waltersdorph, F. M. Huennekens, and B. W. Gabrio. Erythrocyte metabolism. V. Levels of glycolytic enzymes and regulation of glycolysis. J. clin. Invest. $1962,41,1249$.

39. Jacob, H. S., and J. H. Jandl. Unpublished observations.

40. Sheppard, C. W., and W. R. Martin. Cation exchange between cells and plasma of mammalian blood. I. Methods and application to potassium exchange in human blood. J. gen. Physiol. 1950, 33, 703.

41. Murphy, J. R. Erythrocyte metabolism. V. Active cation transport and glycolysis. J. Lab. clin. Med. 1963, 61, 567.

42. Gárdos, G. Akkumulation der Kaliumionen durch menschliche Blutkörperchen. Acta physiol. Acad. Sci. hung. 1954, 6, 191.

43. Dunham, E. T. Linkage of active cation transport to ATP utilization. Physiologist 1957, 1, 23.

44. Whittam, R. Potassium movements and ATP in human red cells. J. Physiol. (Lond.) 1958, 140, 479.

45. Hoffman, J. F. Cation transport and structure of the red-cell plasma membrane. Circulation 1962, 26, 1201.

46. Skou, J. C. The influence of some cations on an adenosine triphosphatase from peripheral nerves. Biochim. biophys. Acta (Amst.) 1957, 23, 394.

47. Post, R. L., C. R. Merritt, C. R. Kinsolving, and C. D. Albright. Membrane adenosine triphosphatase as a participant in the active transport of 
sodium and potassium in the human erythrocyte. J. biol. Chem. 1960, 235, 1796.

48. Dunham, E. T., and I. M. Glynn. Adenosinetriphosphatase activity and the active movements of alkali metal ions. J. Physiol. (Lond.) 1961, 156, 274.

49. Hokin, L. E., and M. R. Hokin. Phosphatidic acid metabolism and active transport of sodium. Fed. Proc. 1963, 22, 8.

50. Charnock, J. S., and R. L. Post. Evidence of the mechanism of ouabain inhibition of cation activated adenosine triphosphatase. Nature (Lond.) 1963, 199, 910.

51. Schatzmann, H. J. Herzglykoside als Hemmstoffe für den aktiven Kalium- und Natriumtransport durch die Erythrocytenmembran. Helv. physiol. pharmacol. Acta 1953, 11, 346.

52. Ponder, E. Hemolysis and Related Phenomena. New York, Grune \& Stratton, 1948.

53. Jacob, H. S., and J. H. Jandl. Effect of membrane sulfhydryl deficiency on the shape and survival of red cells (abstract). Clin. Res. 1961, 9, 162.

54. Jacob, H. S., and J. H. Jandl. Effects of sulfhydryl inhibition on red blood cells. II. Studies in vivo. J. clin. Invest. 1962, 41, 1514.

55. Whittam, R. The asymmetrical stimulation of a membrane adenosine triphosphatase in relation to active cation transport. Biochem. J. 1962, 84, 110.

56. Glynn, I. M. Activation of adenosinetriphosphatase activity in a cell membrane by external potassium and internal sodium. J. Physiol. (Lond.) 1962, $160,18 \mathrm{P}$.

57. Haut, A., G. R. Tudhope, G. E. Cartwright, and M. M. Wintrobe. Studies on the osmotic fragility of incubated normal and abnormal erythrocytes. J. clin. Invest. 1962, 41, 1766.

58. Simon, E. R. Expanded autohemolysis as an investigative and diagnostic tool in hemolytic disorders. Clin. Res. 1963, 11, 200.

59. Murphy, J. R. Erythrocyte metabolism. II. Glucose metabolism and pathways. J. Lab. clin. Med. 1960, $55,286$.
60. Glynn, I. M. The ionic permeability of the red cell membrane. Progr. biophys. 1957, 8, 241.

61. Sen, A. K., and R. L. Post. Stoichiometry of active $\mathrm{Na}^{+}$and $\mathrm{K}^{+}$transport to energy-rich phosphate breakdown in human erythrocytes. Fed. Proc. 1961, 20, 138.

62. Gabrio, B. W., C. A. Finch, and F. M. Huennekens. Erythrocyte preservation: a topic in molecular biochemistry. Blood 1956, 11, 103.

63. Lardy, H. A., and H. Wellman. Oxidative phosphorylations: role of inorganic phosphate and acceptor systems in control of metabolic rates. J. biol. Chem. 1952, 195, 215.

64. I.ynen, F., G. Hartmann, K. F. Netter, and A. Schnegraf, in Ciba Foundation Symposium: Regulation of Cell Metabolism, G. E. W. Wolstenholme and C. M. O'Connor, Eds. Boston, Little, Brown, 1959, p. 256.

65. Rose, I. A., J. V. B. Warms, and E. L. O'Connell. Role of inorganic phosphate in stimulating the glucose utilization of human red blood cells. Biochem. biophys. Res. Commun. 1964, 15, 33.

66. Robinson, M. A., P. B. Loder, and G. C. de Gruchy. Red-cell metabolism in non-spherocytic congenital haemolytic anaemia. Brit. J. Haemat. 1961, 7, 327.

67. Harris, I. M., J. M. McAlister, and T. A. J. Prankerd. The relationship of abnormal red cells to the normal spleen. Clin. Sci. 1957, 16, 223.

68. Griggs, R. C., R. Weisman, Jr., and J. W. Harris. Alterations in osmotic and mechanical fragility related to in vivo erythrocyte aging and splenic sequestration in hereditary spherocytosis. J. clin. Invest. 1960, 39, 89.

69. Bromberg, P. A., J. Theodore, E. D. Robin, and W. N. Jensen. Human erythrocyte $\mathrm{pH}$ with special reference to intracellular acidosis in hereditary spherocytosis (abstract). J. clin. Invest. 1962, 41, 1349.

70. Carroll, L. Through the Looking Glass. 